\title{
PERSPECTIVES
}

\section{Lipoprotein Receptors in the Liver}

\author{
CONTROL SIGNALS FOR PLASMA CHOLESTEROL TRAFFIC
}

\author{
Michael S. Brown and Joseph L. Goldstein, Departments of Molecular \\ Genetics and Internal Medicine, University of Texas Health Science Center \\ at Dallas, Dallas, Texas 75235
}

A decade of intense investigation has established a central role for lipoprotein receptors in regulating plasma cholesterol traffic. These receptors bind cholesterol-carrying lipoproteins and transport them into cells by receptor-mediated endocytosis. The receptor for low density lipoprotein (LDL) was the first discovered; it has been purified and its structure characterized. The LDL receptor was described in cultured human fibroblasts; identical receptors are now known to function in liver as well as in extrahepatic tissues. Operationally, the LDL/LDL receptor system can be considered the primary transport mechanism for endogenous cholesterol. Dietary cholesterol, on the other hand, is transported from the intestine in chylomicron remnants, which enter hepatocytes via distinct chylomicron remnant receptors. The chylomicron remnant/remnant receptor system is to exogenous cholesterol transport as the LDL/LDL receptor system is to endogenous cholesterol transport. In this article, we review recent developments in this rapidly advancing field.

Two hepatic lipoprotein receptors (Fig. 1). Exogenous (dietary) cholesterol is delivered to the liver in chylomicron remnants $(1,2)$, which are derived from intestinal chylomicrons through the action of lipoprotein lipase. The remnants rapidly enter the liver by receptor-mediated endocytosis after binding to specific remnant receptors (3-5). Endogenous cholesterol transport begins when the liver secretes cholesterol into plasma together with triglycerides in very low density lipoproteins (VLDL). After the triglycerides of VLDL are removed by lipoprotein lipase, the re-

Received for publication 5 May 1983. sultant cholesterol-rich particle is designated intermediate density lipoprotein (IDL). IDL particles bind with high affinity to hepatic LDL receptors. Some of the particles are rapidly cleared from plasma by this route; other IDL particles are converted to LDL. The mechanism of this conversion is unknown. LDL is removed relatively slowly from plasma by binding to LDL receptors in the liver and extrahepatic tissues (6). These receptors are genetically and immunologically identical to the LDL receptors of cultured fibroblasts $(4,7)$. In rabbits, rats, and hamsters, more than half of the total LDL receptors are located in the liver $(8,9)$. However, the precise distribution of these receptors in man is unknown.

Appreciation of the separate fates of endogenous and exogenous cholesterol is reinforced by new knowledge concerning apoprotein (apo $)^{1} \mathrm{~B}$, the major structural protein of cholesterol-carrying lipoproteins (10). The apo B synthesized by the intestine (designated apo B-48) is only $48 \%$ as large as the apo B synthesized by the liver (apo B-100). Chylomicrons and chylomicron remnants contain apo B-48. VLDL, IDL, and LDL contain apo B-100, but no apo B-48. Hence, these three particles must arise from endogenous hepatic sources.

Independent regulation of hepatic LDL receptors and chylomicron remnant receptors. Hepatic LDL receptors are suppressed whenever the liver's content of cholesterol increases or its demand for cholesterol is reduced. Thus, receptor suppression occurs when a high cholesterol diet is consumed $(3,11)$ or when bile acids are infused (12). Conversely, LDL receptors increase when hepatic cholesterol synthesis is blocked

\footnotetext{
'Abbreviations used in this paper: apo, apoprotein; $\mathbf{F H}$, familial hypercholesterolemia.
} 

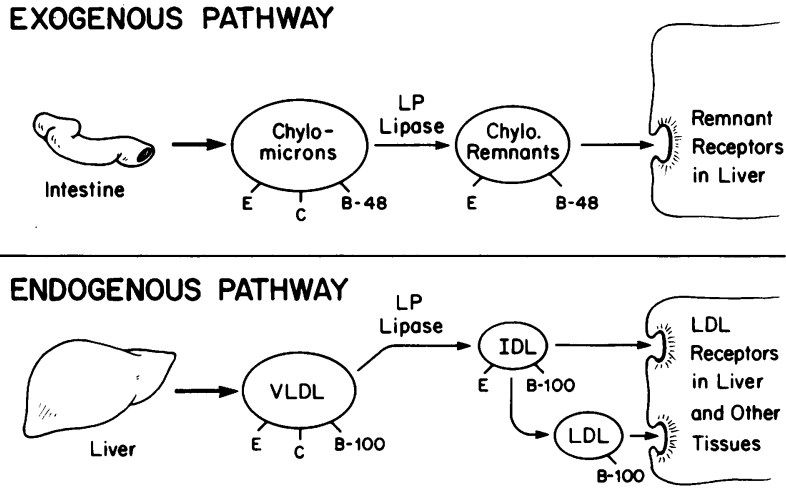

FIGURE 1 Receptor-mediated transport of exogenous and endogenous cholesterol in human plasma. For simplicity, only those apoproteins that play a role in receptor-mediated transport are shown. LP lipase denotes lipoprotein lipase.

by the drugs compactin or mevinolin $(13,14)$, when bile acid binding resins are given $(15,16)$, or when an ileal bypass is created (17). LDL receptors can be stimulated by thyroxine (18) and by pharmacologic doses of estrogen (19). Hepatic LDL receptors decline when rabbits are fed a diet composed only of sucrose and casein (20). In dogs, hepatic receptors fall with ageing (21).

All of the changes in receptor activity alter the rate of uptake of LDL by the liver and cause reciprocal changes in the plasma LDL level. Whenever hepatic LDL receptors are suppressed, the plasma LDL level rises; conversely, whenever these receptors are induced, the plasma LDL level falls.

Chylomicron remnant receptors do not appear to be regulated. Manipulations that affect hepatic LDL receptors do not influence the hepatic uptake of chylomicron remnants, nor do they cause a significant change in the plasma level of these lipoproteins $(1,3)$. The receptors for $\mathrm{LDL}$, and chylomicron remnants are also under separate genetic control. In humans with homozygous familial hypercholesterolemia $(\mathrm{FH})$ and in the Watanabe heritable hyperlipidemic strain of rabbits, there is a genetic absence of LDL receptors in liver and extrahepatic tissues (22). IDL and LDL accumulate in plasma, but chylomicron remnants do not.

Apoproteins that mediate binding to hepatic receptors (Fig. 1). The apoprotein specificity of the two hepatic receptors has been difficult to sort out, since most lipoproteins contain several apoproteins. The LDL receptor recognizes apo B-100, the only apoprotein of LDL. The same LDL receptor also recognizes apo $\mathrm{E}$, a constituent of chylomicrons and chylomicron remnants as well as of VLDL and IDL. Apo $E$ is a 34,000-dalton glycoprotein; its complete amino acid sequence is known (23). The structural features of apo
E that mediate binding to LDL receptors have been elucidated in elegant detail by Mahley, Innerarity, and co-workers. Much of the work has been performed with apo E-HDL $\mathrm{L}_{\mathrm{c}}$, a lipoprotein that accumulates in plasma of cholesterol-fed dogs (24). Although named as an HDL, apo E-HDL $\mathrm{C}_{\mathrm{c}}$ differs from typical HDL in that it contains no apo $\mathrm{A}$; its sole apoprotein is apo $\mathrm{E}$. The affinity of the LDL receptor for apo E-HDL $\mathrm{L}_{c}$ is 20 -fold greater than for LDL (which contains only apo B), but at saturation the receptor binds only one-fourth as many particles of apo E-HDL $\mathrm{H}_{\mathrm{c}}$ as LDL (25). Lipoproteins such as IDL that contain both apo B-100 and apo $E$ bind to LDL receptors with higher affinity than LDL, suggesting that apo $E$ is the preferential ligand. Chylomicron remnants, which contain apo $\mathrm{E}$ and apo B-48, also bind to LDL receptors $(4,26)$.

Certain lipoproteins that contain apo $\mathrm{E}$ do not bind to LDL receptors. In particular, newly circulating chylomicrons and VLDL bind poorly despite their content of apo $E(26,27)$. This poor binding has been attributed to the presence on these triglyceride-rich particles of another family of apoproteins, apo C (2). The apo C's are believed to play a dual metabolic role: They mask the receptor binding site on apo $E$ and they also activate lipoprotein lipase. After the triglycerides have been hydrolyzed by lipoprotein lipase, the apo C's leave the particles and the particles are rapidly cleared from plasma.

Although chylomicron remnants can bind to LDL receptors in vitro, functional and genetic evidence, reviewed above, indicates that most of these particles enter the liver by binding to a separate class of unregulated receptors that do not recognize apo B-100containing lipoproteins (Fig. 1). What is the apoprotein that mediates this specific binding to remnant receptors? Sherrill et al. (28) provided evidence that this function is performed by apo $\mathrm{E}$. They found that apo E-HDL ${ }_{c}$ competes with ${ }^{125}$ I-labeled chylomicron remnants for uptake in perfused rat livers. Moreover, apo $\mathrm{E}-\mathrm{HDL}_{\mathrm{c}}$ binds to liver membranes in vitro at a time when LDL receptors have been metabolically suppressed (3). In view of these binding specificities, hepatic LDL receptors have been called "apo B, E receptors" and chylomicron remnant receptors have been called "apo E receptors." However, since the hepatic apo B, E receptor is now known to be the same molecule as the extrahepatic LDL receptor, this dual nomenclature seems redundant.

The binding of apo $\mathrm{E}$ to both the remnant receptor and the LDL receptor creates a paradox. In certain metabolic and genetic situations, the LDL receptor is suppressed or absent, but the remnant receptor functions normally. Under these conditions the plasma accumulates large amounts of lipoproteins, such as IDL and so-called " $\beta$-VLDL," that contain both apo B-100 
and apo E. If apo E-containing particles can bind to the remnant receptor, why are they not removed from the circulation in vivo? The simplest answer (for which there is no direct evidence) is that apo $\mathrm{E}$ cannot bind to the remnant receptor when it is present on a lipoprotein particle together with apo B-100. Somehow apo B-100 may mask the ability of apo $\mathrm{E}$ to bind to the remnant receptor and thereby direct it to the LDL receptor.

In summary, apo $\mathrm{E}$ is an important determinant of the affinity of lipoproteins for both the chylomicron remnant receptor and the LDL receptor. The decision as to whether a given lipoprotein binds to the remnant receptor or the LDL receptor is controlled by the interaction of apo $E$ with its neighboring apoproteins and perhaps lipids. Through these interactions, exogenous apo B-48-containing lipoproteins are directed to remnant receptors and endogenous apo B-100-containing lipoproteins are directed to LDL receptors.

$F H$ : genetic defect in a receptor. The LDL receptor has an apparent molecular weight of 160,000 as determined by sodium dodecyl sulfate gel electrophoresis and density gradient ultracentrifugation $(29,30)$. The receptor is synthesized in the rough endoplasmic reticulum as a precursor with an apparent molecular weight of 120,000 (31). It undergoes an apparent increase of 40,000 in molecular weight in the Golgi apparatus before its insertion into the plasma membrane. The receptor has both $O$-linked and $N$-linked carbohydrate chains (Cummings, R., S. Kornfeld, W. J. Schneider, K. K. Hobgood, H. Tolleschaug, M. S. Brown, and J. L. Goldstein, manuscript in preparation). The posttranslational increase in size may result from elongation of the $O$-linked chains.

$\mathrm{FH}$ is caused by a mutation in the gene for the LDL receptor. At least eight mutant alleles are known (32). Each mutation disrupts a step in the itinerary of the LDL receptor, affecting its synthesis, posttranslational processing, or localization in coated pits. About one in 500 persons has one mutant gene for the LDL receptor and is thus an FH heterozygote. These individuals produce only half the normal number of functional receptors and hence they degrade LDL at a reduced rate. In the steady state, the level of LDL in plasma is about twofold above normal, and atherosclerosis usually occurs by the fifth decade. About one in 1 million persons inherits two mutant alleles at the LDL receptor locus and is termed an FH homozygote. Often, these individuals inherit a different mutant allele from each parent and thus they are "genetic compounds," analogous to patients with SC hemoglobinopathy. FH homozygotes synthesize no functional receptors or only a very small number. As a result, IDL particles are not cleared normally by the liver and are converted to LDL in increased amounts (Fig. 1). The
LDL, in turn, is catabolized sluggishly, and its accumulation in plasma leads to severe atherosclerosis in childhood (33).

In addition to the high affinity receptor pathway, LDL can be degraded by less efficient receptor-independent pathways. When the LDL receptor is absent, as in receptor-negative $\mathrm{FH}$ homozygotes and Watanabe heritable hyperlipidemic rabbits, these receptorindependent pathways account for all the degradation of plasma LDL (34). Radioactive lipoproteins that are cleared by these low affinity pathways are found in liver and extrahepatic tissues (35). The mechanism of this uptake is unknown.

Measurement of LDL receptor-dependent and -independent pathways in vivo. At a clinical level, it is now possible to estimate the relative amounts of LDL that are catabolized via receptor-dependent and -independent pathways. This is achieved by the simultaneous administration of doubly labeled radioactive lipoproteins, one of which is modified in such a way that it can no longer bind to the LDL receptor. This approach is based on the observation by Mahley et al. (36) that arginine and lysine residues in LDL are required for binding to the LDL receptor. When these residues are modified, LDL cannot be degraded by the receptor, and it is catabolized only by receptor-independent pathways.

The first ligand used for this purpose was cyclohexanedione-modified LDL. Shepherd et al. (37) showed that native LDL was removed from plasma faster than the modified preparation, documenting the role of LDL receptors in vivo. Quantitatively, cyclohexanedione-LDL underestimates the amount of clearance by the receptor pathway because blockage of receptor binding is incomplete and because some of the cyclohexanedione comes off the particle in the circulation $(36,38)$.

Better methods for blocking receptor binding involve methylation or glucosylation of the lysine residues of LDL (Table I). In humans, glucosylated LDL is removed from the circulation only one-fifth as rapidly as is native LDL, indicating that four-fifths of the clearance of LDL is mediated by the receptor pathway (39).

Familial dysbetalipoproteinemia: genetic defect in a ligand. Patients with familial dysbetalipoproteinemia have a marked elevation in apo E-containing lipoproteins (IDL and chylomicron remnants) in their plasma and they develop severe premature atherosclerosis (40). These individuals have two mutant alleles at the apo E locus $(41,42)$. Most commonly, both mutant alleles specify a protein, apo E-2, with a cysteine substituted for an arginine at position $158(43)$. Apo E-2 has a markedly reduced affinity for LDL receptors in intact fibroblasts and liver membranes (44, 
TABLE I

Receptor-mediated Clearance of Plasma LDL In Vivo

\begin{tabular}{llc}
\hline \multicolumn{1}{c}{ Species } & $\begin{array}{c}\text { Modified LDL used to measure } \\
\text { receptor-independent degradation }\end{array}$ & $\begin{array}{c}\text { LDL degraded } \\
\text { by receptors }\end{array}$ \\
\hline \multirow{2}{*}{ Rat } & Methyl-LDL (8, 36) & $\%$ \\
Guinea pig & Methyl-LDL (38) & $50-75$ \\
& Glucosylated LDL (38) & 78 \\
Hamster & Methyl-LDL (9) & 78 \\
Rabbit & Methyl-LDL (34) & 72 \\
& Glucosylated LDL (52) & $67-75$ \\
Rhesus monkey & Methyl-LDL (36) & 50 \\
Human & Glucosylated LDL $(39,53)$ & 80 \\
\hline
\end{tabular}

45). It also binds poorly to chylomicron remnant receptors in liver membranes (Mahley, R. W. and T. Innerarity, unpublished observations). As a result, apo $\mathrm{E}-2$ is cleared from the circulation much more slowly than the normal form of apo $E(46,47)$.

While the above considerations suggest a simple clearance defect as the etiology of this disorder, several observations indicate otherwise: (a) About 1\% of all persons studied are homozygous for the apo E-2 mutation, yet only $1 \%$ of these homozygotes ever have a marked elevation of apo E-containing lipoproteins in plasma (41). (b) Even among the few E-2 homozygotes with the full-blown familial dysbetalipoproteinemia syndrome, plasma lipoprotein levels do not become elevated until adulthood. (c) Despite the homozygous genetic defect, the elevated lipoprotein levels are rapidly reduced by several maneuvers: reduction in caloric intake, administration of clofibrate, or treatment of coexistent hypothyroidism or estrogen deficiency. (d) Pedigree analysis suggests that the full-blown syndrome is expressed most commonly when an individual inherits two independent abnormalities: homozygosity for apo E-2 plus a single copy of a dominant gene that by itself produces another form of hyperlipidemia, such as the gene for $\mathrm{FH}$ (defective LDL receptors) (48) or the gene for familial combined hyperlipidemia (unidentified gene product that leads to overproduction of VLDL) (49).

The above observations suggest that homozygosity for apo E-2 is necessary, but not sufficient, to produce familial dysbetalipoproteinemia. Why do all apo E-2 homozygotes not have extremely high plasma levels of IDL and chylomicron remnants? A clue to the answer is provided by the clinical observation that these patients' lipoprotein levels are exquisitely sensitive to factors that reduce hepatic LDL receptors. Such factors include age, decreased levels of thyroid hormone and estrogen, and the genetic defect in FH (50). These findings suggest that high levels of hepatic LDL receptors are necessary for apo E-2 homozygotes to compensate for their genetic binding defect. Perhaps a small amount of residual binding activity in apo E-2 is sufficient to keep plasma lipoprotein levels low so long as an individual expresses large numbers of LDL receptors. Such compensation might break down when LDL receptors are reduced, as in heterozygous $\mathbf{F H}$, or when the production of VLDL is increased to the point that LDL receptors are overwhelmed, as in familial combined hyperlipidemia.

The complexity of the apo $\mathrm{E}$ binding function is highlighted by several other mutations at this locus. A family has been described in which several siblings lack apo $E$ entirely, apparently as a result of homozygosity for a null allele at the apo $E$ locus. These individuals have the classic syndrome of familial dysbetalipoproteinemia (51). In addition to the apo E-2 and null alleles, six mutant alleles with different amino acid substitutions have been identified (Mahley, R. W. and $T$. Innerarity, unpublished observations). In most cases, the abnormal apo $E$ have diminished LDL receptor-binding activity and cause familial dysbetalipoproteinemia. However, one abnormal apo E (arg $\rightarrow$ cys at position 145) binds nearly normally to LDL receptors when tested in vitro, yet the individual who posesses two copies of this allele has the full-blown syndrome $(43,44)$. Clearly, a full understanding of familial dysbetalipoproteinemia will require a more complete knowledge of the mechanisms by which the lipid and protein components of lipoproteins affect the receptorbinding activity of apo $\mathbf{E}$.

\section{ACKNOWLEDGMENT}

The authors' research is supported by a grant from National Institutes of Health (HL-20948).

\section{REFERENCES}

1. Sherrill, B. C., and J. M. Dietschy. 1978. J. Biol. Chem. 253:1859-1867.

2. Windler, E., Y-S. Chao, and R. J. Havel. 1980. J. Biol. Chem. 255:5475-5480.

3. Hui, D. Y., T. L. Innerarity, and R. W. Mahley. 1981. J. Biol. Chem. 256:5646-5655.

4. Kita, T., J. L. Goldstein, M. S. Brown, Y. Watanabe, C. A. Hornick, and R. J. Havel. 1982. Proc. Natl. Acad. Sci. USA. 79:3623-3627.

5. Cooper, A. D., S. K. Erickson, R. Nutik, and M. A. Shrewsbury. 1982. J. Lipid Res. 23:42-52.

6. Kita, T., M. S. Brown, D. W. Bilheimer, and J. L. Goldstein. 1982. Proc Natl. Acad. Sci. USA. 79:5693-5697.

7. Beisiegel, U., T. Kita, R. G. W. Anderson, W. J. Schneider, M. S. Brown, and J. L. Goldstein. 1981. J. Biol. Chem. 256:4071-4078.

8. Carew, T. E., R. C. Pittman, and D. Steinberg. 1982. J. Biol. Chem. 257:8001-8008. 
9. Spady, D. K., D. W. Bilheimer, and J. M. Dietschy. 1983 Proc. Natl. Acad. Sci. USA. 80:3499-3503.

10. Kane, J. P. 1983. Annu. Rev. Physiol. 45:637-650.

11. Kovanen, P. T., M. S. Brown, S. K. Basu, D. W. Bilheimer, and J. L. Goldstein. 1981. Proc. Natl. Acad. Sci. USA. 78:1396-1400.

12. Angelin, B., C. A. Raviola, T. L. Innerarity, and R. W. Mahley. 1983. J. Clin. Invest. 71:816-831.

13. Goldstein, J. L., and M. S. Brown. 1982. Clin. Res. 30:417-426.

14. Bilheimer, D. W., S. M. Grundy, M. S. Brown, and J. L. Goldstein. 1983. Proc. Natl. Acad. Sci. USA. In press.

15. Shepherd, J., C. J. Packard, S. Bicker, T. D. V. Lawrie, and H. G. Morgan. 1980. N. Engl. J. Med. 302:12191222.

16. Kovanen, P. T., D. W. Bilheimer, J. L. Goldstein, J. J. Jaramillo, and M. S. Brown. 1981. Proc. Natl. Acad. Sci. USA. 78:1194-1198.

17. Spengel, F. A., K. Harders-Spengel, R. Duffield, C Wood, N. B. Myant, and G. R. Thompson. 1982. Res. Exp. Med. 180:263-270.

18. Thompson, G. R., A. K. Soutar, F. A. Spengel, A. Jadhav S. J. P. Gavigan, and N. B. Myant. 1981. Proc. Natl. Acad. Sci. USA. 78:2591-2695.

19. Windler, E. E. T., P. T. Kovanen, Y.-S. Chao, M. S. Brown, R. J. Havel, and J. L. Goldstein. 1980. J. Biol. Chem. 255:10464-10471.

20. Chao, Y.-S., T.-T. Yamin, and A. W. Alberts. 1982. J. Biol. Chem. 257:3623-3627.

21. Mahley, R. W., D. Y. Hui, T. L. Innerarity, and K. H Weisgraber. 1981. J. Clin. Invest. 68:1197-1206.

22. Goldstein, J. L., T. Kita, and M. S. Brown. 1983. N. Engl. J. Med. In press.

23. Rall, S. C., Jr., K. H. Weisgraber, and R. W. Mahley 1982. J. Biol. Chem. 257:4171-4178.

24. Mahley, R. W., and T. L. Innerarity. 1983. Biochim. Biophys. Acta 737:197-222.

25. Innerarity, T. L., R. E. Pitas, and R. W. Mahley. 1980 Biochemistry. 19:4359-4365.

26. Florén, C.-H., J. J. Albers, B. J. Kudchodkar, and E. L. Bierman. 1981. J. Biol. Chem. 256:425-433.

27. Gianturco, S. H., F. B. Brown, A. M. Gotto, Jr., and W. A. Bradley. 1982. J. Lipid Res. 23:984-993.

28. Sherrill, B. C., T. L. Innerarity, and R. W. Mahley. 1980 J. Biol. Chem. 255:1804-1807.

29. Schneider, W. J., J. L. Goldstein, and M. S. Brown. 1980. J. Biol. Chem. 255:11442-11447.

30. Schneider, W. J., U. Beisiegel, J. L. Goldstein, and M. S. Brown. 1982. J. Biol. Chem. 257:2664-2673.

31. Tolleshaug, H., J. L. Goldstein, W. J. Schneider, and M. S. Brown. 1982. Cell. 30:715-724.

32. Tolleshaug, H., K. K. Hobgood, M. S. Brown, and J. L. Goldstein. 1983. Cell. 32:941-951.
33. Goldstein, J. L., and M. S. Brown. 1983. Familial hypercholesterolemia. Chapter 33. In The Metabolic Basis of Inherited Disease. J. B. Stanbury, J. B. Wyngaarden, D. S. Fredrickson, J. L. Goldstein, and M. S. Brown, editors. Fifth ed. McGraw-Hill Book Co., New York. 672-712.

34. Bilheimer, D. W., Y. Watanabe, and T. Kita. 1982. Proc Natl. Acad. Sci. USA. 79:3305-3309.

35. Pittman, R. C., T. E. Carew, A. D. Attie, J. L. Witztum Y. Watanabe, and D. Steinberg. 1982. J. Biol. Chem. 257:7994-8000

36. Mahley, R. W., K. H. Weisgraber, G. W. Melchior, T. L. Innerarity, and K. S. Holcombe. 1980. Proc. Natl. Acad. Sci. USA. 77:225-229.

37. Shepherd, J., S. Bicker, A. R. Lorimer, and C. J. Packard. 1979. J. Lipid Res. 20:999-1006.

38. Steinbrecher, U. P., J. L. Witztum, Y. A. Kesaniemi, and R. L. Elam. 1983. J. Clin. Invest. 71:960-964.

39. Kesaniemi, Y. A., J. L. Witztum, and U. P. Steinbrecher. 1983. J. Clin. Invest. 71:950-959.

40. Mahley, R. W., and B. Angelin. 1983. Adv. Intern. Med. In press.

41. Utermann, G., M. Hees, and A. Steinmetz. 1977. Nature (Lond.). 269:604-607.

42. Zannis, V. I., and J. L. Breslow. 1981. Biochemistry. 20:1033-1041.

43. Rall, S. C., Jr., K. H. Weisgraber, T. L. Innerarity, and R. W. Mahley. 1982. Proc. Natl. Acad. Sci. USA. 79:4696-4700.

44. Schneider, W. J., P. T. Kovanen, M. S. Brown, J. L Goldstein, G. Utermann, W. Weber, R. J. Havel, L. Kotite, J. P. Kane, T. L. Innerarity, and R. W. Mahley. 1981. J. Clin. Invest. 68:1075-1085.

45. Rall, S. C., Jr., K. H. Weisgraber, T. L. Innerarity, R. W. Mahley, and G. Assmann. 1983. J. Clin. Invest. 71:1023-1031.

46. Havel, R. J., Y-S. Chao, E. E. Windler, L. Kotite, and L. S. S. Guo. 1980. Proc. Natl. Acad. Sci. USA. 77:43494353.

47. Gregg, R. E., L. A. Zech, E. J. Schaefer, H. B. Brewer, Jr. 1981. Science (Wash. DC). 211:584-586.

48. Hazzard, W. R., J. J. Albers, P. Baron, N. Miller, G. R. Warnick, and B. Lewis. 1981. Lancet. I:298-301.

49. Hazzard, W. R., G. R. Warnick, G. Utermann, and J. J. Albers. 1981. Metab. Clin. Exp. 30:79-88.

50. Brown, M. S., P. T. Kovanen, and J. L. Goldstein. 1981. Science (Wash. DC). 212:628-635.

51. Ghiselli, G., E. J. Schaefer, P. Gascon, and H. B. Brewer, Jr. 1981. Science (Wash. DC). 214:1239-1241.

52. Sasaki, J., and G. L. Cottam. 1982. Biochim. Biophys. Acta. 713:199-207.

53. Bilheimer, D. W., S. M. Grundy, M. S. Brown, and J. L. Goldstein. 1983. Trans. Assn. Am. Phys. In press. 